\title{
PHF20 wt Allele
}

National Cancer Institute

\section{Source}

National Cancer Institute. PHF20 wt Allele. NCI Thesaurus. Code C106059.

Human PHF20 wild-type allele is located within 20q11.22-q11.23 and is approximately $178 \mathrm{~kb}$ in length. This allele, which encodes PHD finger protein 20 , is involved in transcriptional regulation and histone acetylation. 